\title{
Survey of Teletherapy in Japan
}

\section{Part I. Accumulated numbers of teletherapy units installed in hospitals and their tendency ${ }^{\dagger}$}

\author{
Hiroshi YASUKOCHI \\ Department of Radiology, City Hospital Constructing \\ Bureau, Koshigaya City \\ 343 Koshigaya 1-1-1, Koshigaya City, Saitama Prefecture
}

For the purpose of decision and selection of the teletherapy unit to be installed in the Koshigaya city hospital, surveys of teletherapy units in Japan were performed in several ways.

First, a survey was performed on the units made by five companies (Toshiba Medical Systems Co. Ltd., Shimadzu Seisakusho Co. Ltd., Hitachi Medical Corponation Co. Ltd., Nippon Electric Co. Ltd., Chiyoda X-ray Co. Ltd.,), from which the lists of hospitals installed their units were offered. The units installed by other companies were considered to be almost zero in number. The survey of Okinawa prefecture was in. cluded although the data during the occupation period by the U.S.A. were not exact, and the number was assumed to be so small that this would not influence the results of this survey.

The number of telecobalt units installed in hospitals was linearly increased during the period from 1955 to 1973 as indicated by the formula of $Y=30 \mathrm{X}$, where ' $Y$ ' is the accumulated number of the units installed and ' $X$ ' is the years passed from 1955. However, when the units were divided in this survey into two types, the stationary type and the rotational type, the number of stationary type was gradually decreasing its rate of increase from 1960 and seemed to have been saturated since 1973 and, on the contrary, the number of rotational type was accelerated its rate of increase from 1965 but seems also to trend toward saturation from 1973 as shown in Fig. 1. The rate of increase of the total number was mainly influenced by that of stationary type till 1960 and by that of rotational type after 1965.

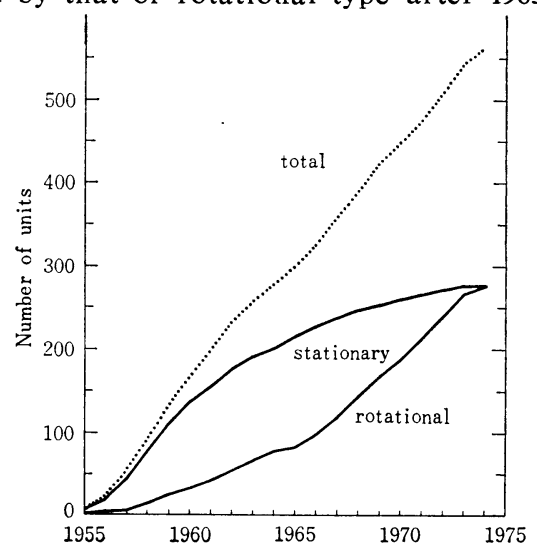

Fig. 1 Accumulated number of telecobalt units installed in hospitals in Japan (including discarded units)

The saturation of the number of cobalt units was assumed to depend partly on the lack of radiologists and partly on the increased number of units per population and on the recently developed stability of linear accelerators of lower energy which are now in use as the replacement of cobalt unit.

Betatrons were started to be used in hospitals in 1961 and their number has increased since then. The rate of increase of the number was high between 1965 and 1970 as

†日本に扣ける放射線治療の現状について 第 1 報 放射線治療装置設置の現状と傾向, 安河内浩: （343）越谷市越谷1-1-1 越谷市々立病院建設事 務局 放射線部門 
indicated by the formula of $Y=6.7 X-57$ and then gradually turning to saturation. Before 1965 the majority of units were the lower energy type of under $19 \mathrm{MeV}$ but since 1968 the installation of these lower energy type in hospitals has been saturated. The higher energy type of over $20 \mathrm{MeV}$ was installed at a high rate of increase from 1965 but gradually starting for saturation from 1970 as shown in Fig. 2.

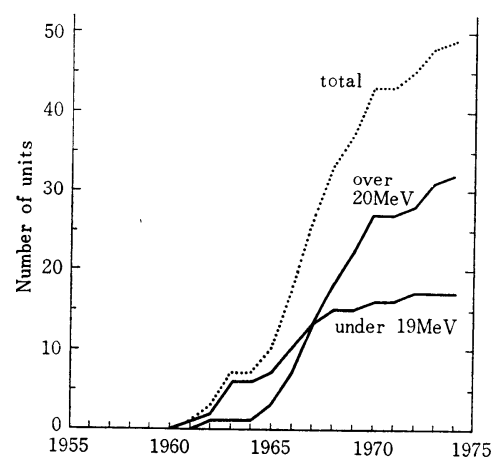

Fig. 2 Accumulated number of betatrons installed in hospitals in Japan (including discarded units).

The saturation of the betatron was assumed to depend upon its lower output specially in X-rays and upon the development of higher energy linear accelerators which could also be used for higher energy electron therapy.

The installation of linear accelerators was started in 1963 and the number increased linearly from 1967 as indicated by the formula of $Y=12.5 X-137.5$ and was still increasing as shown in Fig. 3.

In the case of linear accelerators the increasing line of lower energy type of under $9 \mathrm{MeV}$ was almost in agreement, as shown in Fig. 3, with that of higher energy type of over $10 \mathrm{MeV}$ after 1970, and the total numbers of these two types at present was almost the same.

The lower energy type was replacing the telecobalt unit because of its higher output and emotional apprehension about radioisotopes in Japanese people. The increase of higher energy units is assumed to be due to its additional capacity for high energy electron therapy which was previously covered

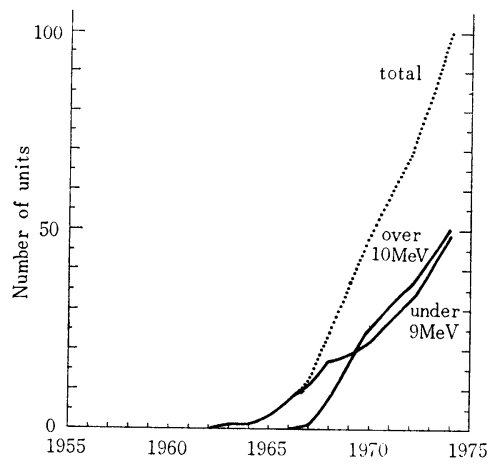

Fig. 3 Accumulated number of linear accelerators installed in hospitals in Japan (including discarded units).

only by betatrons.

At present about 500 units of telecobalt (about 250 each of stationary and rotational), about 50 units of betatron and about 100 units of linear accelerator have been installed for radiotherapy among the whole population of about $110,000,000$ in Japan. This means that about 220,000 persons are covered by one cobalt unit, about $2,200,000$ persons by one betatron and about $1,100,000$ persons by one linear accelerator.

Since the hospital now blue-printed in Koshigaya city is to cover about 200,000 , it needs about 0.9 unit of cobalt, 0.1 unit of betatron and 0.2 unit of linear accelerator that means about 1.3 teletherapy units for the city hospital to maintain the mean value per hospital of teletherapy units installed in Japan, although the actual number is considered to be smaller because some of these units have been already discarded and some others are used for smaller populations.

Taking these points into consideration, we have decided to install one therapy unit at the opening of the hospital and chosen one higher energy linear accelerator because of its rather wide utility in comparison with other units and also the widely acceptable needs of linear accelerators as will be suggested by their increasing number of installation in hospitals.

I wish to express my thanks to the companies mentioned above for kindly sending me their data for this survey. 